\title{
Local Government and Road Infrastructure Delivery: Nigeria Experience
}

\author{
Ayotunde David Odewale \\ Department of Local Government and Development Studies, \\ Obafemi Awolowo University Ile-Ife, Osun State, Nigeria \\ Correspondence Author: mailto:odewaleayo@hotmail.com
}

\begin{abstract}
Abstrak: Penyediaan infrastruktur esensial dan dasar, terutama di tingkat Pemerintah Lokal di Nigeria merupakan peran utama dalam pembangunan sosial-ekonomi dan politik, dan dalam meningkatkan taraf hidup di akar rumput. Sayangnya, infrastruktur jalan berada dalam kondisi dilema terutama jalan Pemerintah Daerah karena banyak kendala. Makalah ini bermaksud untuk melihat kendala ini dan menawarkan solusi yang mungkin. Baik metode primer dan sekunder digunakan. Makalah tersebut menemukan bahwa jalan pemerintah daerah merupakan batang jalan tertinggi, dan yang meningkat dari hari ke hari karena kedekatannya dengan penduduk, namun, jalan yang paling diabaikan di Nigeria. Akhirnya, beberapa rekomendasi diartikulasikan.
\end{abstract}

Kata kunci; Pembangunan; Pemerintah daerah; Pembangunan dan Pemeliharaan Jalan; Pengiriman Layanan; Infrastruktur Sosial.

\begin{abstract}
The provision of essential and basic infrastructure, especially at the Local Government level in Nigeria constitutes a major role in socio-economic and political development, and in improving the standard of living at the grassroots. Sadly, the road infrastructures are in a state of dilemma particularly the Local government roads due to so many constraints. The paper intends to look at these constraints and proffer possible solutions. Both primary and secondary methods were employed. The paper discovered that local government roads constitute the highest trunks of roads, and which got increasing day-by-day due to its proximity to the populace, and yet, the most negligible trunk of road in Nigeria. Finally, some recommendations were articulated.
\end{abstract}

Keywords: Development; Local Government; Road constructions and Maintenance; Service Delivery; Social Infrastructure.

Article History:

Received: 5-8-2020; Revised: 25-9-2020; Accepted: 10-11-2020

\section{INTRODUCTION}

For a nation or society to function efficiently and effectively there must be adequate infrastructural facilities available for the citizenry. Rural infrastructure is a broad term covering the basic facilities and services needed for rural communities and rural development (FAO, 2006). The provision of essential and basic infrastructure, especially at the Local Government level constitutes a major role in socio-economic and political development, and in improving the standard of living at the grassroots. In the Nigerian federal system, all three tiers of government have responsibilities to perform in delivering services to the populace. The provision of road infrastructures is one of the services provided by all tier of government, i.e federal, state and local government.

In Africa, and particularly Nigeria, has continually suffered the epidemic bad road network which has resulted in serious havoc on the populace. The highways are in bad shape, the street roads are not palatable, and the rural roads are also in a stage of comatose. Many lives have been lost, while some have been damaged due to the bad stage of Nigeria roads. Nigeria's economy also remains in shambles due to the poor road network both in rural and urban areas. This calls for serious attention. One of the major concerns of any tier of government is to engage in the provision of basic infrastructure for the populace through different means available to them. Khoza (2009) opines that 
the provision of infrastructure ensures to improve the livelihoods of the citizens and their quality of life.

Nigeria road network is majorly divided into three categories and trunks, i.e. trunk A, trunk B, and trunk $\mathrm{C}$. Trunk A is meant for the federal government to construct and maintain, trunk B for state government, and trunk $\mathrm{C}$ for Local Government. All these tiers of government have the responsibility to construct the new road network and maintain the existing ones in the area of their jurisdiction. More so, they could relate to each other in construction or maintenance in intergovernmental capacities and context. In taking a critical look at these categories of the road network and the situation of these roads, one needs to agree that there is a need for a serious review of this arrangement, especially on local government roads (Trunk $\mathrm{C}$ road) which got increased day by day. Also, there is no doubt that the majority of the federal highways (Trunk A) and State roads (Trunk B) are eyesores throughout the federation compared to that of developed countries. The socio-economic development of Nigeria largely depends on the availability of good road infrastructure network across the nook and cranny of the country. Sehinde (2008) observes that the establishment of Local Government in Nigeria arises from the need to facilitate rural development through infrastructural development and service delivery. Appadorai (1975) asserts that there are problems that are better handled by the local government because they are local, and are better understood by the local people themselves. Udoh (2005) also asserts that over two-thirds of Nigeria's population resides in local areas, where poverty prevails, and they still lack access to electricity, access to potable water, access to good roads. Provisions of the entire basic infrastructure are necessary to reduce vulnerability and poverty at the grassroots level.

The importance of Local Government in the development process is based on the imperative to tackle local socio-economic problems and to manage grassroots development through the provision of this basic infrastructure such as good road network (Wunsch, 2001; Anwar \& Sana, 2006). Lawal (2014) asserts that despite the constitutional provisions for Local Government in Nigeria to embark on the provision of infrastructural that would make life comfortable for the grassroots, lack of adequate, affordable and reliable infrastructural facilities persists at the local level. Federal, State and Local roads are in bad states and this hurts agricultural potentials, which is one best way for Africa to move out of endangering poverty that pervaded the continent.

Sadly, in Nigeria today, the "overriding impression is that Local Governments are weak in responding to the challenges posed by rural infrastructural provision" (Lawal 2014). World Bank (2004) asserted that the quality and quantity of infrastructure in Nigeria is grossly inferior and inadequate compared to other parts of the world. The World Bank report further revealed that the quality of infrastructure in Nigeria was ranked 99th position out of 102 countries that were assessed in the global competitiveness report of 2004. In Africa, the density of Nigeria roads was described as the lowest (Alabi and Ocholi, 2010). Though, it is gradually changing for good.

Both rural and urban Local Government Areas are in a pathetic and deficient state of infrastructural delivery. Most of the infrastructure, where available even faced the problem of proper and adequate maintenance (Lawal, 2014). This implied that Local Governments have failed to attain their responsibilities in the creation, construction, and maintenance of roads efficiently and effectively. Local roads are in a state of dilemma due to long years of existence, lack of maintenance, lack of a quality job, uncompleted nature of the projects and absence of community ownership of such projects. The paper is divided into seven sections. The first section deals with introduction, methodology is the second section, and the third section discusses conceptual clarification, while the fourth section explores the road network in Nigeria. The fifth section discusses local government and road infrastructure delivery in Nigeria. The sixth section analyses the challenges confronting Local Government on road delivery. The last section presents recommendation and conclusion.

\section{RESEARCH METHOD}

Secondary and primary source of data were used. The secondary data were source through the use of documentary research technique which gathers information and analyzes it by simple content analysis of documents, articles, records and academic research projects. Primary data were gathered through observation methods. 


\section{HASIL DAN PEMBAHASAN}

\section{Local Government}

The concept of Local Government differs from one environment to another. These differences could not be overemphasized due to the various perspectives on the actual roles and functions to discharge. Robson (1949) sees local government as "a territorial non-sovereign community possessing the legal rights and necessary organization to regulate its affairs". They have defined territory, legal backing and ability to deal with the affairs of the local populace. There is no doubt that each Local Government in Nigeria is distinctly mapped out territorially, yet we cannot dispute the problem of boundary adjustment here and there in the country. So also, Local Government is still subject to the control and supervision of other tiers of government. In Nigeria context, Local Government is seen as the third tier of Government that is lower to that of national and state, and not only that they just perform functions stated by other tiers, but they have their constitutional functions clearly stated.

Eneanya (2012) asserts that some of the reasons for the establishment of local government are to create a platform for people to conduct their affairs in line with local needs and aspirations; provide an underlying structure for local development in a way to mobilize and sustain popular zeal; provide a hedge against over-concentration of power at the center and encourage decentralization of powers to the local populace; provide a channel of communication between the local populace and the central government. Aransi (2012) sees the local government council as "a sub-national government run by a body (elected or appointed) and established by law over a defined territory with authority to generate and utilize resources for the development of its locality and well-being of its citizens". Local government plays a crucial role in the delivery of services to the citizenry. The success of any local government is its ability to utilize its human and material resources to achieve the desired objectives i.e., rendering needed services to the community. Local government is a level of government in which popular participation both in the choice of decision-makers and in its recognition as the third tier of government are keyed.

\section{Social Infrastructure}

The concept of social infrastructure has emerged over the last decades and a lot of research has been conducted across the globe. Duffield (2001) believes that public or social infrastructure is the most apparent form of construction that interests the society at large. Infrastructure could also differ from one field to another. Lawal (2014) sees infrastructure as "an umbrella term for many activities, basic structure, and facilities necessary for the efficient functioning of a country". In the same vein, "Infrastructure is also seen as the totality of basic physical facilities upon which all other economic activities in a system depend" (African Development Bank, 1999). Infrastructure comprises the assets needed to access the economic and social facilities, such as roads, electricity, water, drainage, bridges, etc. which is lacking in Nigeria nation, particularly at the grassroots level. Infrastructure could be categorized as social or economic. "It encompasses both public and private assets, including public services, the economic sector as well as social contributors influencing living standards and quality of life" (Grimsey \& Lewis, 2004). "Social infrastructure encompasses municipal, education, health, housing, justice, and recreational assets, which ameliorate human development, quality of life and living standards" (Howes \& Robinson, 2005). In nigeria context, municipal means the government at the local grassroots level, which is christened as 'local government' with abilities to provide primary education, primary health, road infrastructure among others in other to improve the quality of life and increase the living standards of the populace. Gramlich (1994) also asserts that "economic infrastructure is constituted from large, long-standing structures such as transportation, power, communications and utility systems which facilitate economic activities".

Concerning infrastructure, the 1987 US National Research Council panel adopted the term "public works infrastructure", which refers to both the specific functional modes and the combined system these modal elements comprise, which include highways, streets, roads, and bridges; water supply and water resources; mass transit; airports and airways; solid-waste treatment and disposal; electric power generation and transmission; telecommunications; and hazardous waste management. Argy, Lindfield, Stimson \& Hollingsworth (1999) further differentiate social infrastructures into two forms which include hard social and soft social infrastructure. The hard social infrastructure includes hospitals, while soft social infrastructure includes social security. William (1991) also classifies infrastructure into hard and soft infrastructure and also refers to hard infrastructure as "the physical 
networks necessary for the functioning of a modern industrial nation while soft infrastructure may refer to the institutions which are required to maintain an economy".

Social infrastructure may also involve a wider range of partners which include; government agencies, private agencies, and non-profit organizations together with a selection of user groups, freelance scientists, independent consultants as well as academic research institutes (Oppen, Sack \& Wegener, 2005). So also, infrastructure may be owned and managed by governments or by private companies or may be established through Public-Private Partnership (PPP) arrangements. Furthermore, the term "public works" also includes government-owned and operated infrastructure as well as public buildings, and also covers social infrastructure, such as schools and housing. Social infrastructure generally refers to the physical assets needed to deliver public services. Public services include both infrastructure and services generally provided by the government; therefore, social infrastructure is an integral part of public service delivery.

The 1999 Constitution of the Federal Republic of Nigeria stipulates specific functions for each tier of government. The mandatory, concurrent and permissive functions stipulated for the Local Government are more of infrastructure in nature than any other service delivery. One of the challenges of social infrastructure in Nigeria setting, particularly at the Local Government level, is that they usually attract less attention among the stakeholders within the community.

\section{Discourse on Developmental School of Thought}

The justification for this school is that local government permit resources both human and material, to be mobilized for rural development (Eminue, 2006), which means that local government are strategically placed to stimulate grassroots development and bring about rural transformation. Tony (2011) also argues that the basic need for the creation of the local government is developmental in nature, because the essence of encouraging democratic participation and efficient service delivery are ultimately development oriented in order to improve the social and economic lives of the people at the grassroots. This school differs from the democratic-participation and efficient service school of thought over its ethnocentric bias in favour of developed Western democracies. It argues that from Alex-de-Tocqueville and J.S. Mill to James Bryce and to contemporary theorists such as James Sharpe, William Mackenzie and Hugh Whalen, there were a lot of emphasis on Western Europe and Northern American (Fatile, Majekodunmi, \& Adejuwon, 2013). Much more, developmental school emphasized on how local government in the developing world can be an effective agent of better life socially and economically, and for the grassroots to share in the national wealth.

Eminue, (2006) also observes that the developing nations have come to appreciate the fact that the only meaningful and sustainable form of development is that which is endogenous, i.e. development which emanates from the will and desire of the people rather than one imposed from outside (exogenous development) and that the more superior developmental approach is the "bottomup" rather than the "top-down" or directive approach. Ola, (1988) was of the opinion that local government exist in a way to helps in decongesting government at the centre from unnecessary involvement in local issues in order to fast track development.

Adeyemo (2010) also asserts that this school of thought has clearly made the development of the citizens and their environment the core functions of local government. In a way, the construction of roads, hospitals, schools, markets and other infrastructures by various local governments in Nigeria would contribute immensely to national development. The activities of each local government towards providing these services to the local populace in their jurisdictions would cumulatively result in improved level of national development. It is therefore affirmed that all services which constitute the core of Local Government's activities are national in character, and nationally important. Neglect of any of these services in any part of the country will reduce the overall level of development in such country. This school of thought is of the opinion that summations and aggregation of developments at various local areas transform to national development. In fact, most of the services that constitute the core functions of local government are national in character. For instance, health, education, water supply and roads are nationally important. Any attempt to neglect local government to perform these functions efficiently would deter the progress and development of the country especially, the local roads. Chukwuemeka, Ugwuanyi, Ndubuisi-Okolo, \& Onuoha, (2014) posit that "the development role of the local government is even appreciated in the context of overall national development 
efforts". The operational role of local government appear so captivating that if it does not exist, something else would have to be created to replace it.

This school of thought sees local government as an essential tool for the promotion of national integration and consciousness (Abutudu, 2011). It serves as an instrument for development, national integration and national consciousness by breaking down dysfunctional parochialism against such development, and in a way creates an awareness that sees life beyond the locality, but more of national integration. In Africa, particular, Nigeria, this dysfuntionality continued to be evident in the stage of bad road network in various localities which deterred the expected development at the local level, and even at the national level. However, the empirical linkage between local government and national development is more critically highlighted by the developmental school. The school opines that local government could be an agent to better the lives of the citizens, improves standard of living, develops manpower resources, brings about social and economic development, and at the end of it all, the aggregation would lead to national development.

In Nigeria, local governments serve as reliable companions with other tiers of government in providing services that would cumulate to national development, but this companionship has not been sufficiently encouraged to unlock its developmental potential. Decentralization or devolution of governmental powers to the local government affords the opportunity of participation in the development process to the local or grassroots people (Chukwuemeka et al, 2014). These opportunities for developmental process to the grassroots have not been harnessed in Nigeria local government system due to the fact that local governments are not financially viable in order to provide some services expected from them.

Maddick (1963) also notes that local authorities provide the opportunity for the grassroots to participate in local decisions and schemes within the general national policies and to act above all, as local centres of initiative to development. One of the cardinal points of present governments in Nigeria is agricultural development, on which the rural road networks constitute a major pillar in agricultural development. The stage of rural roads in Nigeria is in comatose and need serious attention from all tiers of government and other non-governmental stakeholders.

\section{ROAD NETWORK IN NIGERIA}

The transport system in most countries is made up of four major categories namely: rail, road, water, and by air. However, in sub-Saharan Africa road transport dominate other modes of transport (Sanni, 2007). Despite the emergence and importance of economic reality in Nigeria, road network continues to represent the arteries of the economy through which the country's economic activities flow at local, regional and national levels (Boswell, 2003). The governments of Nigeria have invested heavily in the development of road infrastructure. Yet the services of this sector have "remained generally poor" (Buhari, 2000). Over the years, in Nigeria, the development and maintenance of roads have been shared between the three tiers of government (Abdulkareem, 2003). Therefore, Nigerian roads can be categorized into three i.e the federal roads, the state roads, and the local government roads.

\section{The Federal Government Road Network}

The federal roads are also known as the trunk A road. Trunk A Road is seen as the skeleton form of the national road grid. These roads cut across geo-political zones and state boundaries in the country. It also, extends to the international borders of neighboring countries, especially in West Africa. Trunk A road is constructed, maintained and financed by the Federal Government through the Federal Ministry of Works. Usually, the government agency responsible for the maintenance of these categories of the road is called the Federal Road Maintenance Agency (FERMA). This road could be a two-lane highway, dual carriageways and express/highway with some high quality. In addition to road networks, the federal government is also responsible for airports, railways waterways, and seaports.

\section{The State Government Road Network}

Trunk B Road is also seen as the second category of main roads in Nigeria. This category of the road is expected to links the major cities within States, and that of the State headquarters. These roads are constructed, maintained and financed by the State governments. Trunk B road is usually a tarred 
road and its primary objective is to enhance the socio-economic development of the State. Every State Government has the responsibility toward the delivery of this service to the populace in their jurisdiction.

\section{The Local Government Road Network}

Trunk C Roads are local feeder roads constructed and maintained by the local government authorities. This class of road is usually tarred or untarred and seasonal. These roads link streets to streets, neighbouring villages, and local communities within the centre of the towns and other remote parts of each local government. This class of roads consists of the highest among the trunks of the road in Nigeria. The more the new streets and settlements emerge, the more the increase in trunk $\mathrm{C}$ road. A benchmark of an average of 100 vehicle traffic daily or any other criterion that is appropriate to it is expected to constitute local roads. Anything above this should be the role of the state government to manage such roads (NTP, 2010).

\section{Local Government and Road Infrastructure Delivery in Nigeria}

The federal trunk road are the roads which link the major parts in the country, the state capitals and urban centers, major centers of economic activity and major boundaries to neighboring countries, while the state roads are the ones which feeds into federal trunk roads and the farm-to-market roads and the third one, which is local roads, consists of rural roads and city streets, which are the responsibilities of local governments (Abdulkareem, 2003).

It is also pertinent to state here that road construction has become a major component of Nigeria's capital budgets at the federal and state levels, especially since the oil boom era in the 1970s (Adeoti, 2000). The national road network grew from its total length of $6,500 \mathrm{Km}$ in 1960 to $10,000 \mathrm{Km}$ in 1970 to $29,000 \mathrm{Km}$ in 1980 , and as at 2003 , is estimated at $200,000 \mathrm{Km}$ (Adelana, 2003). The breakdown of the stock of the federal roads network consists of $32,100 \mathrm{~km}$ highways; the state governments consist of $30,500 \mathrm{~km}$; and the local governments with about $130,600 \mathrm{~km}$. This combined together shows that Nigeria had a stock of road network of 194,000 km with the federal government responsible for about $17 \%$, state government $16 \%$, and local government $67 \%$ (CBN, 2003).

This shows that the bulk of roads are the responsibility of local governments in Nigeria yet they are also the tier of government with the lowest financial allocation from the federation account. Though, the report of CBN showed the above percentage in the year 2003, there are drastic changes in estimated kilometers of road in Nigeria, especially on local government road due to the nature of the trunk $\mathrm{C}$ in Nigeria. Local government roads got increasing day-by-day, due to the emergent of the new settlement. These roads cut across both urban and rural settlements, even in the state capitals. The roads spread across in megalopolis, conurbations, cities, and towns. Also, local government roads constitute majorly in villages, hamlets, homestead and streets, especially in Nigeria due to their closeness to the grassroots, and which make this trunk of road to got increasing day-by-day and little or no attention were given from the local government, particularly because of their financial constraints, responsibilities ambiguity, and inadequate proper approach to tackle this menace.

The Constitution provided for each tier of government to have independent responsibilities for the planning, financing, and maintenance of their roads in their jurisdiction. Badejo \& Odewale (2018) also assert that most of the time, state governments embark on construction and maintenance of roads which are more of local roads and finance the project with local government funds or with joint funding in the name of Joint Account Allocation Committee (JAAC). There are cases where the state government awards the local government roads as a contract on behalf of local government in the name of the state-local relation. If efficiency must take its place concerning the provision of social service in the area of unilateral (mandatory) or joint (concurrent) funding, especially in road construction there is a need for proper assessment so that the generality of the populace would be able to know which tier of government to hold responsible for the particular project or otherwise for a joint responsibility.

The major components of any road networks are observed to include the following; accessibility of the road, connectivity of the roads to one another, traffic density on such roads, compactness of the roads and level of service on such roads. (Mannering, Walter \& Scott, 2004). Oduwaye (2004) asserts that with good accessibility, a good road network has a way of influencing 
property values and improved transportation facilities. The major essence of rural roads is to provide a means of evacuating farm products to market, raw materials to industries and to also enhance efficient service delivery at the local level, especially in the areas of agriculture, health, education, and social development. However, most of the Local Governments in Nigeria still lack the needed capacity building to discharge their responsibility in terms of financial resources and technical know-how. "Due to competing needs, government allocation to the road network sub-sector over the years has been dwindling, and now grossly inadequate. Because of the social service functions of roads, the government cannot but continue to contribute to the funding" (NTP, 2010).

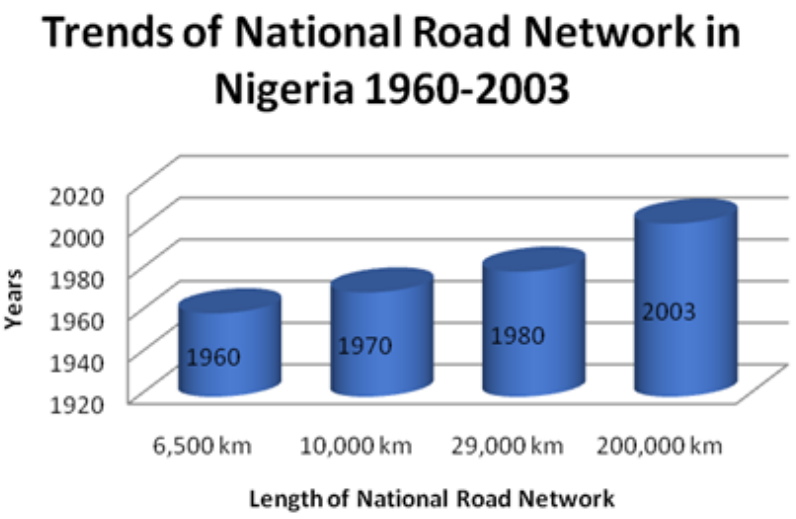

Figure.1 Trends of National Road Network in Nigeria

The figure. 1 above highlighted the trends at which national road network grew between the year 1960 of independence and year 2003. The road network has obviously assumed to grow more than $200,000 \mathrm{~km}$ of 2003 due to the emergent of the new settlements both in urban and rural areas.

\section{Breakdown of the Road Network across the Three Levels of Government in Nigeria in Kilometres}

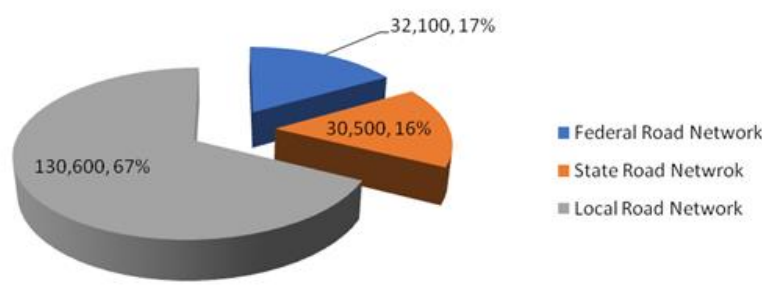

Figure.2 Breakdown of the Road Network across the Three levels of Government in Nigeria

The figure. 2 shows that the bulk of roads are the responsibility of local governments in Nigeria yet they are also the tier of government with the lowest financial allocation from the federation account. Not only that local government roads keep increasing day-by-day due to their closeness and proximity to the grassroots, yet little or no attention were given to the construction and maintenance of this salient trunk of road network.

\section{Challenges of Local Government on Road Delivery}

Inadequate Autonomy: This has been established by various scholars, as one of the challenges confronting the local government in delivery services to the grassroots. In the area of road construction at the local level, inadequate autonomy, especially from the state government has constituted a major clog for local government in Nigeria to be more efficient and effective (Odewale \& Badejo, 2018). The 1999 constitution of the federal republic of Nigeria recognized local 
government as the third tier of government with specific functions to perform stipulated clearly, and construction and maintenance of road is one of them, but most of the times, local government may not be able to embark on this functions until permission is being given from the state government, despite that road construction and maintenance are more of mandatory and exclusive function for local government.

Ambiguity of Responsibilities: Local government ought to be responsible for trunk C road, while the State and Federal Governments are responsible for trunks B and A respectively, but often time, due to closeness of local government to the populace, and negligence of state and federal governments on their own assigned roads, the populace customarily expect the local government to help out in repairing such roads, especially when such roads are strategic to the free flow of goods and services. Also, the construction and maintenance of road have been identified as one of the mandatory and exclusive functions of the local government particularly on trunk $\mathrm{C}$ road, but the ambiguity in identifying trunk B from C are evident. Frequently, State Governments embarked on construction and maintenance of roads in trunk $\mathrm{C}$ which is typically meant for local government to construct. Also, local government repairs on trunk $\mathrm{A}$ and $\mathrm{B}$, even without any intergovernmental relations with the tiers of government concerns.

This also buttress the submission of Badejo \& Odewale (2018) that Local government repairs trunk A road which is federal roads, they embarked on this due to the peculiarity and exigency of that road, not minding which tiers of government are responsible. The state government diverts the attention of local government more to concurrent functions while the mandatory functions which include road construction and maintenance suffer (Odewale \& Adepoju, 2020). This ambiguity of clear cut responsibilities for all the tiers of government is more evident on trunk $\mathrm{C}$ which is a local government road.

Unfavorable Fiscal Structure: The fiscal structure of local government remains one of the major banes that affect the delivery of services at the local government in Nigeria. The structure and activities of the JAAC in various states of the federation have constituted a threat for local government in constructing and maintaining road networks in their jurisdictions. After various deductions by the state government from this joint account, the balance becomes dearth for the provision of infrastructures, especially the road network. Odewale \& Benson (2016) also affirm that state-local fiscal relation seems to be unfavorable to political leaders through the illegal deduction of local government funds in Nigeria, in disguise of joint account by the state governments. The fiscal structures of Nigeria have a highly observable barrier in delivery of essential infrastructure at the local government level (Odewale, 2019). This unfavorable fiscal structure has crippled the local government in discharging their functions independent of state government.

Lack of Community Ownership: One of the major problems confronting existing infrastructures particularly in the road sector at the grassroots level in Nigeria is the absence of community ownership. The proper synergy between the service providers (government) and service users (residents) is in a mirage. The residents see these infrastructures as more of government properties than a sense of local ownership, which invariably affect the way it's being nurtured and maintained. This is in tandem with the position of Odewale (2019) that absence of community ownership has contributed to the challenges facing the sustainability of infrastructure delivery in Nigeria local government. The requisite cooperativeness and collaboration between the service providers and users are deficient and dearth. The principle of self-help which encourages communalism, cooperativeness and collectiveness is not embedded among the residents to see the infrastructure provided by the government as their own and nurtured it accordingly.

Lack of Maintenance Culture: This is similar to that of community ownership but slightly different in the sense that community ownership tends more to the residents or service users, while maintenance culture tends more to the governments or service providers. Most of the local government roads in Nigeria lack proper maintenance culture. Until the roads are in devastating state, it may not cut the attention of the government, even the citizens plying through the roads exhibit a lackadaisical attitude until the roads becomes ridiculously damaged and unmotorable. Odewale (2019), also observes that the maintenance cultures of public infrastructures in Nigeria are very poor, the government provide services to the populace and most of the time turn their back to that provision without thorough and continuous monitoring, while on the other hand, the populace which is the users of the service do not even bother to sustain and maintain that infrastructure, any little fault, the 
infrastructure becomes useless and nobody cares about repairs. He also concluded that poor maintenance culture constituted a notable challenge on social service delivery particularly at local government level in Nigeria. This is evident in Nigeria road networks, particularly in Trunk C, which constitute part of the sole responsibilities of the grassroots government.

Lack of Quality Job: Poor performance in the road construction and the use of substandard materials for selfish gains is another concern and limiting factor to the good infrastructure delivery in Nigeria. This can be attributed to lack of transparency and the power politics in the award of government contracts, which deters efficiency in government facilities, not limited to the road infrastructures alone. Therefore, the qualities of the job delivery are sabotaged. Improper Accountability: Often time local government engaged in construction and maintenance of road on a concurrent template with the state government, through the instrumentality of JAAC, which need proper accountability because both tiers of government have the mandate to be held accountable independently. There exist various road projects being financed with local government funds through JAAC, but the populace still gives the kudos to the state government alone without necessary accolade to the local government.

Odewale \& Adepoju, (2020) suggest a paradigm shift from this encroachment, in other to allow local government to be appropriately accountable to the citizens. Most of the joint road projects by state and local government are being accrued to the state government, instead of sharing the accolade in the sight of the populace.

Corruption: It is in right context to assert that corruption is another major limiting factor confronting the efficient delivery of government services. The corrupt practices which limit effective delivery in government services, is another important factor to address in the local government road infrastructure delivery. Enyioku, Akinlo, Franklin \& Odewale (2015) also conclude that corruption is the greatest bane of local government in Nigeria, and that it has been canonically accommodated, entertained, and celebrated within the governmental system. Corruption among others is detrimental to provision of social service in achieving the goals of sustaining development and sustainability which is in mirage (Odewale \& Benson, 2016). Noticeable, in the selfish ambition of some state Governors, which hijack local government functions in order to perpetrate fraud and deter transparency in the local service delivery. More so, corruption at the local government in Nigeria are not limited to state Governors that siphon the local government funds, but much more, the local government officials. The leadership at the local government are not free of corruption which eventually have negative impact on service delivery, particularly road in infrastructure.

\section{CONCLUSION}

Local government roads in Nigeria, constitute the highest trunks of roads, and which got increasing day-by-day due to its proximity to the populace, and yet, the most negligible trunk of road in Nigeria. The essential template of sound governance is that capacities should be given to the levels of government that has the knowledge and understanding of the problem according to their responsibilities, therefore necessary attention is needed to be given to the local roads in order to increase the socio-economic, and in improving the standard of living at the grassroots.

It has also become imperative to reassign the responsibilities of the three tiers of government by reducing the percentage of local government to the bearable level that would accommodate their resources or otherwise to increase their allocation to accommodate these enormous responsibilities, especially in the road sector. An essential template of sound governance is that capacities should be given to the level of government that has the knowledge and understanding of the problem according to their responsibilities.

Due to the enormous responsibilities of local government on road construction and maintenance, there is a need to reassign the responsibility in order to empower the local government financially to tackle this difficulty. However, federal government can spend less on trunk A road by building the highways into an international standard, and engage the service of private sector on Public Private Partnership for adequate maintenance. Thereafter, the proceeds from the partnership with the private sector could be used to develop the trunk $\mathrm{C}$ roads. More so, financial autonomy of local government from state government would also help in developing a sustainable trunk $\mathrm{C}$ road in Nigeria. 
There is need for proper accountability and necessary accolade between the state and local government in service delivery, particularly in road sector. There are cases where the construction of road on trunk B or C would be done by state government but being financed by local government fund or jointly with the state government, and the populace would have the perception that the road is been provided by state government, without knowing the financial input of local government.

Due to the closeness and proximity of local government to the populace, there is need for local government to establish an efficient structure to relate and reconcile especially on maintenance of roads, even on trunk A, B and C, in case of emergency. Proper synergy between the stakeholders could lead to a sustainable development in construction and maintenance of roads in Nigeria.

Also, there is need for town planning in each local government of the federation to describe and determine a very clear road network in terms of accessibility, connectivity, compactness, density and maintenance particularly on local government roads. So also there should be a deliberate effort by the government to encourage communities to continue with self-help schemes in solving the problem of a rural road.

\section{REFERENSI}

Abdulkareem, Y. A. (2003). Road Maintenance Strategy, so far, how far. Nigerian Society of Engineers Workshop on sustainable maintenance, strategy of Engineering Infrastructures, llorin, Nigeria.

Abutudu, M. (2011). The Challenges and Opportunities for Improving the Local Government System in Nigeria. Paper Prepared for Presentation at the Third Biennial National Conference on Community Development in Nigeria Held at Grand Hotel, Asaba, November, 20-24, 2011.

Adelana, O. O. (2003). Budgeting for Roads Infrastructure Maintenance. Conference Proceedings of the Nigerian Institution of Civil Engineer (A division of the NSE) Lagos, Nigeria.

Adeoti, K. A. (2000). Strategies for improving Intra Urban Mass transit Operation in Nigeria: A case study of Kwara State. NSE "Technical Transactions, A Publication of the Nigerian Society of Engineers (NSE) 35(3), July - Sept. Edition Lagos, Nigeria.

Adeyemo, D. O. (2010). Public-Private Partnership and Strategic Management at the Local Government. Paper Presented at the National Workshop on Structure and Functions of Nigerian Local Government for Efficient Service Delivery at the Grassroots Level by the National Forum of Chairmen of Local Government Service Commission of Nigeria. 13- 15 March.

African Development Bank (1999). Infrastructure Development in Africa, African Development Report 1999. Oxford University Press.

Alabi, M. O., \& Ocholi, I. (2010). State of Infrastructure and Funding in Kogi State, Nigeria, Current Research Journal of Social Sciences, 2(3), 209-213.

Anwar, Shah (2006). Local Governance in Developing Countries: Public Sector Governance and Accountability Series. The World Bank Herndon, VA, USA as Panacea for Service Delivery. International Journal of Business and Social Science, 2(16), 386-398.

Appadorai, A. (1975). The Substance of Politics New Dehil, Oxford University Press.

Aransi, I. O. (2012). Local Government Administration In Comparative Perspective: A Comparative Performance Analysis Of Elected And Appointed Local Councils In Nigeria. USA: Warren Publishing Inc.

Argy, F., Lindfield, M., Stimson, B., \& Hollingsworth, P. (1999). Infrastructure and Economic Development, CEDA Information Paper No. 60, Committee for Economic Development of Australia, Melbourne.

Badejo, B. T., \& Odewale, A. D. (2018). Unveiling the Dichotomy Between State and Local Government Projects: A Special Reference to Primary Education and Road Construction in Southwestern Nigeria. Journal of Arts and Humanities, 7(12), 33-42. 
Boswell, F. (2003). Maintenance of Civil Engineering Infrastructures for sustainable Development with Reference to Road Maintenance. Conference Proceedings of the Nigerian Institution of Civil Engineers (A division of the NSE), Lagos, Nigeria.

Buhari, Muhammed. (2000). The Role of Infrastructural Development and Rehabilitation in Sustainable Economic Growth in Nigeria. (www.anppusa.org)

CBN (2003). Highway Maintenance in Nigeria: Lessons from other countries. (Research Department Occasional Paper No. 27

Chukwuemeka, E., Ugwuanyi, B. I., Okolo, P., \& Onuoha, C. E. (2014). Nigeria Local Government: A Discourse on the Theoretical Imperatives in a Governmental System. African Review An International Multidisciplinary Journal, 8(2), 305-324.

Duffield, C. F. (2001). An Evaluation Framework for Privately Funded Infrastructure Project in Australia, Unpublished Phd Thesis, Department of Civil and Environmental Engineering, University of Melbourne, Melbourne.

Eneanya, A. N. (2012). Local Government Administration in Nigeria: A Comparative Perspective. Lagos: University of Lagos Press.

Enyioku, C. O., Akinlo, I., Franklin, U. A., \& Odewale, A. D. (2015). Appraisal of Problems and Administration of Urban Local Government in Nigeria: A Case Study of Abeokuta South Local Government, Ogun State. The Quarterly Journal of Administration, 34(2), $105-124$

Eminue, Okon. (2006). The Theory of Local Government: The Indispensability of Local Governance in Operationalizing The Fundamental Principles of Peoples-Centredness. In Akpanim. N. Ekpe (ed), The Substance of Local Government Administration in Nigeria (Theory \& Practice). Lagos: Absot Graphics.

Fatile, J., Majekodunmi, A., Oni, A., \& Adejuwon, D. (2013). Issues in Public Administration and Local Government: The Comparative Perspective, Lagos: Concept Publication Limited.

Food and Agricultural Organization. (2006). Technical Consultation on Rural Infrastructure Issues on Rural Infrastructure and Challenges. www.fao.org/ag/magazine/ags-infra.pdf.

Gramlich, E. M. (1994). Infrastructure investment: A review essay. Journal of Economic Literature, $3(2), 56-69$.

Grimsey, D., \& Lewis, M. K. (2002). Evaluating the Risks of Public Private Partnerships for Infrastructure Projects. International Journal of Project Management. 20(2002), 107-118.

Howes, R., \& Robinson, H. (2005). Infrastructure for the built environment: global procurement strategies. Oxford ; Burlington, MA: Elsevier Butterworth-Heinemann.

Khoza, R. (2009). Sustainable Infrastructure Delivery Through Regional Cooperation. A paper presented at the 4th Environment Conference, Zambia, May 18, 2009.

Lawal, T. (2014). Local Government and Rural Infrastructural Delivery in Nigeria. International Journal of Academic Research in Business and Social Sciences, 4(4), 139- 147.

Maddick, H. (1963). Democracy, Decentralization \& Development: Asia Publishing House, Bombay.

Mannering, F. L., Walter, P. K., \& Scott S. W. (2004). Principles of Highway Engineering and Traffic Analysis. 3rd ed. NJ: John Wiley \& Sons.

National Transport Policy (NTP). (2010). Federal Government of Nigeria Draft National Transport Policy August, 2010.

Odewale, A. D. (2019). Challenges of Local Government on Social Service Delivery in Southwestern Nigeria (1999-2018) International Journal of Politics and Good Governance, 10(10.2), 1-18.

Odewale, A. D., \& Adepoju, B. M. (2020). An Apparasail of Local Government on Mandatory Functions in Southwestern Nigeria (1999-2019). American Journal of Social Sciences and Humanities, 5(2), 250-259.

Odewale, A. D., \& Badejo, B. T. (2018). Social Service Delivery in Southwestern Nigeria: Local Government Perspective. Journal of Public Administration and Governance, 8(4), 294-310. 
Odewale, A. D., \& Benson, K. S. (2016). Political Leadership Structure and Service Delivery in Osun State Local Governments of Nigeria: An Empirical Analysis. Journal of Sustainable Development in Africa, 18(1), 99-116.

Oduwaye, L. (2004). Land Value Determinants in Medium Density Residential Neighbourhoods of Metropolitan Lagos. Journal of the NITP, 17(1), 97-111.

Ola, R. (1998). Some Thoughts on the Role of Local Government in Developing Countries (Nigeria) In Ademolekun L. and Olown, O. (eds.) Local Government in West Africa Since Independence. Lagos: University of Lagos Press.

Oppen, M., Sack, D., \& Wegener, A. (2005). Germany: Private-Public Partnerships in Personal Social Services. New Directions in a Corporatist Environment. in G. Hodge and C. Greve (Eds), the Challenge of Public-Private Partnerships: Learning from International Experience, Edward Elgar, Cheltenham.

Robson, N. (1949). Local Government, in The Encyclopedia of the Social Sciences, 1(9), 1-23.

Sanni, I. (2007). The Economic Effects Of Government Spending On Road Infrastructure In Nigeria. An M.Sc. Project Report Submitted to the Department Of Economics University Of Nigeria, Nsukka.

Sehinde .B. (2008). "Need for a Review of Statutory Roles of Local Government for Effective Service. Journal of Contemporary Politics, 1(1), 102.

Tony, O. (2011). Key Issues in Local Government and Development: A Nigerian Perspective. Enugu: Praise House Publishers.

Udoh, E. J. (2005). Technical Inefficiency in Vegetable Farms of Humid Region; An Analysis of Dry Season by Urban Women in SouthSouth Zone, Nigeria. J. Agric. Soc. Sci., 1(1) 80- 85.

US National Research Council. (1987). Infrastructure for the 21st Century, Washington, D.C.: National Academy Press.

William, A. N. (1991). The soft infrastructure of a market economy Cato Journal, 11(2), 233-238.

World Bank. (2004). World Development Report 2004: Making Services Work for Poor People. Washington, DC: World Bank.

Wunsch, J. (2001). Decentralization, Local Governance and Recentralization in Africa. Public Administration and Development, 21(4), 277-288.

The 1976 Local Government Reforms guidelines, Lagos, Federal Ministry of Information. 1999 Constitution of the Federal Republic of Nigeria 1999, Lagos: Federal Government Press. 